\title{
Speech Acts Found in Inaugural Addresses of Barack Obama
}

\author{
Widya Oktarini \\ Universitas Muhammadiyah Jember \\ (widya.oktarini@unmuhjember.ac.id)
}

\begin{abstract}
This research analyzes the speech acts and language style found in inaugural addressess of the presidents of The United States; Barack H. Obama. This research aims at describing kinds and functions of speech acts, the compliance and violation of cooperative principle. This research is descriptive qualitative using socio-pragmatics approach. In collecting the data, it uses simak method and note-taking technique. In analyzing the data, it uses contextual method by using socio-pragmatics theory. In presenting the results of the analysis, it uses informal method by verbal language. The results of the analysis showed: (a) there were six kinds of speech acts found in the inaugural addresses, specifically: assertive, directive, comissive, expressive, and declarative in which declarative found in Obama's second inaugural address with one data only (b) the functions of speech acts found are: (i) to give opinion, (ii) to inform, (iii) to give direction, (iv) to promise, (v) to express feelings (vi) to declare and to (vii) maintain relationship.
\end{abstract}

Keywords: speech acts, inaugural addresses, Obama, socio-pragmatics.

As a medium of communication, language can have various functions that can be used by humans for various purposes. According to Barker (in Mulyana, 2005) language has a function as naming or referring to efforts to identify objects, interaction functions, emphasize various ideas and emotions, and through language, information can be conveyed to others, this is what is called the transmission function of language. The purpose of language also follows its function of connecting messages or information between human beings.

One application of the function of the language is the mind set forth in the form of speech. Based on the nature and contents, the speech is divided into various types, one of which was the president's inauguration speech. The president's inauguration speech is a speech containing the objectives to be achieved by the president at the ceremony which was commemorated as a sign that the beginning of his office had begun. In American society, the president's inauguration speech reflects the lives of Americans who are rooted in socio-cultural values. Therefore, the speech act used by the president is interesting to study, considering its function as a means of the president's view of the country's condition and also on the work plan that will be carried out.

Speech act is a language process where the speaker not only says, but also does something through speech. So, a speech is not only a representation of meaning, but also contains power. In addition, Rahardi 
(2005) also states that speech act is a concrete manifestation of language functions, which is the basis of pragmatic analysis. Austin (1962: 94-107) divides speech acts into three kinds of acts, namely locutionary acts, illocutionary acts, and perlocutionary acts. Locutionary acts is "the act of saying something", illocutionary acts is "the acts of doing something". Perlocutionary acts is "the act of affecting someone" In addition, Searle in Wijana (1996: 17-19) suggests that at least speakers can realize three things in a speech, namely: locutionary acts, illocutionary acts, and perlocutionary acts.

Related to the definition of speech acts, speech act is divided into five types by Searle in Rohmadi (2004:32), they are: representatives, directives, expressive, commisive, and declarative. Representatives (assertives) is a speech act that binds the speaker to the truth for what he says. The type of act in this speech acts are the act of stating, demanding, acknowledging, showing, reporting, giving testimony, mentioning, speculating. Directive speech acts are speech acts that are intended by the speaker to make his partner do things that is stated in his speech. This type of speech acts include the act of asking, inviting, coercing, suggesting, urging, telling, billing, ordering, urging, pleading, challenging, and giving orders. Expressive speech acts are speech acts that is intended by the speaker to make the speech interpreted as an evaluation of the things mentioned in the speech includes the act of saying thank you, complaining, congratulating, flattering, praising, blaming, and criticizing. Commissive speech acts are speech acts that bind the speaker to carry out everything mentioned in his speech, for example, swearing, promising, threatening, declaring ability. Declarative speech acts are speech acts that are intended by the speaker to create new things (status, circumstances, etc.) The type of this speech acts are the speech with the intention of impressing, deciding, canceling, prohibiting, granting, permitting, classifying, lifting, and forgiving.
Based on these explanation, the aim of this research is to find out the types and function of speech acts used by Obama in inaugural address.

\section{Method}

The method used in this research is descriptive method, which is describing data based on speaker's empirical facts of life. In addition, this study also uses qualitative methods, because the research data is not in the form of numbers but in the form of lingual units such as words, phrases or sentences. Data are collected from speech text by using simak method as proposed by Sudaryanto (1993: 133) that is listen to the inaugural adresses and then use note-taking technique to make the transcription of the speech to be selected and then grouped based on the kind of speech acts. Then the data are analyzed by using contextual methods. Furthermore, the data are presented by informal methods. By using this method, the result of the analysis is presented by giving description in the form of words, because there is no diagram or table.

\section{Results and Discussion}

Types and Function of Speech Acts Found in Inaugural Address of the President of the United States

Types and functions of speech acts found in the inaugural addresses of the presidents of the United States include assertive speech act, directive speech acts, commissivespeech acts, expressive speech acts, declarative speech acts, and phatic speech act.

\section{Assertive Speech Act}

In this illocutionary speaker is bound to the truth of the propositions expressed. This speech act usually contains information and there are facts that can be proven by the speech. Examples of these speech acts, for example, state, propose, brag, complain, 
express opinions, and report.

Assertive speech act found in Obama's inaugural address can be seen in the following:

(1)"That we are in the midst of crisis is now well understood. Our nation is at war, against a far-reaching network of violence and hatred"..... (O1)

Speech act in data (1) is an assertive speech acts because the utterance contains a sentence that include information and it is also an affirmation. This speech act is conveyed implicitly because there were no performative verb that show the speech act. Assertive speech act functions on the data above is to express Obama's opinion about the fact in America that the American country is facing a crisis, namely the war against chaos and destruction that has been much expanded. Through this speech act, Obama wanted to inform the public about evidence of a deteriorating situation in America but still can be fixed together. Therefore, the purpose of this speech act is to convince the American public to work together to rebuild the country under the American administration of Barack Obama.

(2)“Today I say to you that the challenges we face are real. They are serious and many"..... (O1)

In data (2) above, the speech act found is an assertive speech act. This is confirmed by the presence of say performative verbs which means to declare. Declare is a type of assertive speech act. The function of this assertive speech act is to express opinions on the truth on the ground that America faces many truly serious and real challenges. But in the next sentence Obama assured the public that this was America, then all possibilities could occur. Likewise with the challenges facing America, a solution will be found. Thus, it can be concluded that assertive speech acts here have a function to inform about the state of America that the challenges to be faced will be so many and real, but it is still possible to make changes if Americans do it together.

(3) "Our challenges may be new. The instrument with which we meet them may be new. But those values upon which our success depends-honesty and hard work, courage and fair play, tolerance and curiousity, loyalty and patriotism - these things are old". ...(O1)

In this utterance (3), the speech act that is found is an assertive speech act, because this utterance contains information and statements about Obama's opinion. This speech act has a function to express Obama's opinion about new challenges that might be faced by Americans. To face this new challenge, Obama also stated that the tools used were also new. But Obama also believes that the success of Americans will depend on the values of hard work, honesty, steadfastness and fairness, tolerance and curiosity and patriotism that have long been existed. Thus, this speech act has a function to express opinions.

(4)...."each time we gather to inaugurate a president we bear witness to the enduring strength of our constitution. We affirm the promise of our democracy. We recall that what binds this nation together is not the colors of our skin or the tenets of our faith or the origins of our names"...(O2)

Speech acts on speech (4) found in this data are assertive speech acts, which are marked by the presence of an affirmative performative verb. Affirming included in the type of assertive speech act. This assertive speech acts is to express assurance. In this context, Obama stated that every time Americans gather to appoint a president, Americans testify to the strength of the country's constitution. Therefore, it was reaffirmed the promise of the democracy of the United States that all 
American citizens are one, and that which bound them is not skin color, nor belief, or the origin of their names. Obama wants to emphasize that this is the constitutional power and democracy of the United States.

(5) “Today we continue a neverending journey to bridge the meaning of those words with the realities of our time”... (O2)

In this data (5), the speech act found is assertive speech act, because the meaning of the speech sentence is about information and is an affirmation of speech. The function of assertive speech acts in this context is to express Obama's opinion that now the American people continue their journey to realize constitutional power and democracy in America, but must be carried out by citizens because history records that it never happened, even though freedom is God's gift, but must be guaranteed by His people.

(6) "And for more than two hundred years, we have"... (O2)

In data (6) this speech act found is an assertive speech act, because the meaning of the sentence from speech is an information. This assertive speech acts has a function to express Obama's opinion about the freedom of rights and happiness that has been carried out by Americans for 200 years. This is also an affirmation and emphasis of Obama's ideas on Obama's previous utterances.

\section{Directive Speech Act}

The Directive speech acts are speech acts that encourage listeners to do something. The purpose of this speech act is for the partner to take action in accordance with what the speaker said. These illocutionary examples, for example: ordering, begging, demanding, and giving advice.
The directive speech act found on the data will be described as follows:

(7)..."The time has come to reaffirm our enduring spirit; to choose our better history; to carry forward that precious gift, that noble idea, passed on from generation to generation: the God-given promise that all are equal, all are free, and all deservea chance to pursue their full measure of happiness".(O1)

In the data (7) above, the speech acts found are directive speech acts that are implicitly expressed, because no performative verbs are found that indicate the type of speech act. Directive speech acts on this data have a function to tell indirectly. Through this speech, Obama wants to tell Americans to revive their enthusiasm, choose the path of good history, valuable gifts, and noble ideas that are passed on from generation to generation.

(8) “In reaffirming the greatness of our nation, we understand that greatness is never a given. It must be earned".

(O1)

In this data (14), the speech act that is found is a directive speech act because the meaning of the sentence in the speech is an order marked by the verbmust, which means a necessity, which means an order or command. Therefore, this speech act has a function to tell. In this context, Obama told Americans indirectly to work hard to achieve greatness for the United States. This is also a continuation of the previous sentence which states that to achieve the greatness of a nation, it cannot be taken for granted, but must with work hard.

(9)..."We must pick ourselves up, dust ourselves off, and begin again the work of remaking America”. (O1) 
In this data (9), the speech acts found are directive speech acts which are characterized by the presence of performatif verb must which means a necessity. Therefore, this speech act has a function to command Americans directly. In this context, Obama intends to command Americans to rise from adversity, improve themselves, and start working to renew America to be better.

(10)...” The question we ask today is not whether our government is too big or too small, but whether it works - whether it helps families find jobs at a decent wage, care they can afford, a retirement that is dignified. Where the answer is yes, we intend to move forward. Where the answer is no, programs will end. And those of us who manage the public's dollars will be held to account - to spend wisely, reform bad habits, and do our business in the light of day because only then can we restore the vital trust between a people and their government"...(O1)

In this data (16), the speech acts found is directive speech act that is expressed indirectly. This speech act is characterized by the meaning of a sentence which means to persuade. The function of directive speech acts on this data is to invite or persuade Americans to do good things, namely spending money wisely, changing bad habits, and doing business honestly. This is intended to restore the trust between the people and the government.

(11)..."Now, more than ever, we must do these things together, as one nation and one people".(O2)

In this data (11), the speech act found is a directive speech act which is characterized by the presence of performative verbs which means a necessity. The function of directive speech acts on this data is to ask Americans directly to make changes together to advance the American state. Obama also called on Americans to have a sense of nationalism and a sense of unity as a nation and state.

(12) "We understand that outworn programs are inadequate to the needs of our time. So we must harness new ideas and technology to remake our government, revamp our tax code, reform our schools, and empower our citizens with the skills they need to work harder, learn more, reach higher"....(O2)

In this data (12), the speech acts found are directive speech acts because they are characterized by the presence of performative verbmust. The directive speech acts on this data has a function to invite the American people to reorganize the government by improving ideas, overhauling tax rules, reforming schools, empowering citizens to work and study harder, to be able to achieve higher things. However, Obama also reminded that changes in these facilities will not change the goals of the American people that they continue to reward the efforts of every American. These things are what Obama means as something that gives real meaning to their beliefs.

(13) "We, the people, still believe that every citizen deserves a basic measure of security and dignity. We must make the hard choices to reduce the cost of health care and the size of our deficit. But we reject the belief that America must choose between caring for the generation that built this country and investing in the generation that will build its future".. (O2) 
The speech act found in data (13) is a directive speech act which is characterized by a must performative verb which means it must be a command or order. This directive speech act is expressed indirectly because it uses the news sentence mode. Directive speech acts in this context has a function to get Americans to make difficult choices for reducing health care costs, because every citizen has the right to get basic security and dignity.

\section{Commisive Speech Act}

In Commissive speech acts is the speech acts that bind speakers to future actions. Commissive speech acts found in the data will be described as follows:

(14)..."We will build the roads and bridges, the electric grids and digital lines hat feed our commerce and bind us together"... (O1)

In this data (26) speech act found is commissive speech act because of the presence of performative verbwill that promises an action in the future. The function of commissive speech acts on this data is to promise Americans about the changes that Obama has taken in his administration, starting with the construction of bridges and electricity, and digital routes for trade purposes. Then proceed with rearranging science and technological advances to improve the quality of health care and reduce its costs. In addition, the use of natural resources such as wind and land is also planned as a substitute for fuel for cars and factories. Changes in schools and campuses to meet the development of the times are also things that will be done by Obama during his administration.

(15)"We will begin to responsibly leave Iraq to its people, and forge a hard-earned peace in Afghanistan. with old friends and former foes, we'll work tirelessly to lessen the nuclear threat, and roll back the specter of a warming planet"(O1)

The speech act found in data (27) is a commissive speech act because it is characterized by the presence of performative verb will that shows actions to be taken in the future. In this context, commissive speech acts has a function to give promises and convince Americans to stop the war in Iraq and provide peace to Afghanistan. In addition, it is also functioned to make a promise and make people believe that America will work hard tiredlessly to reduce the nuclear threat and the danger of warming the earth and will not forgive the wrong way of life and also will not defend it. To people who want to push their goals by terrorizing and massacring innocent people, Obama also promises that the spirit of Americans is stronger and Americans can defeat them.

(16) “To the people of poor nations, we pledge to work alongside you to make your farms flourish and let clean waters flow; to nourish starved bodies and feed hungry minds"... (O1)

In this data number (16), the speech act found is a commissive speech act because it is characterized by performative verbpledge which means promise. This speech act has a function to express Obama's promise to poor countries about actions he will take to them in his reign to work with them and make their lives prosperous. Obama's promise here is an action he will take in the future, so this utterance is commisive speech act.

(17)“Through blood drawn by lash and blood drawn by sword, we learned that no union founded on the principles of liberty and equality could survive half-slave and half-free. 
We made ourselves a new, and vowed to move forward together". (O2)

In this data (17), the speech act found is commissive speech act which is emphasized in the last sentence mainly through the performatif verb vowed which means to promise. This speech acts has a function to give promises to Americans as a form of Obama's commitment of being elected as president of America in the present. Obama in his reign promised to make the state and citizens of America become new people and then move together to improve America in the future.

(18)“This generation of Americans has been tested by crises that steeled our resolve and proved our resilience. A decade of war is now ending. An economic recovery has begun. America's possibilities are limitless, for we possess all the qualities that this world without boundaries demands: youth and drive; diversity and openness; an endless capacity for risk and a gift for reinvention. My fellow Americans, we are made for this moment, and we will seize it -- so long as we seize it together". (O2)

In this data (18) the speech act found is a commissive speech act which is existed in the last sentence. This speech act is characterized by the presence of performative verb will. This commissive speech act spoken by Obama has a function to convince the American people to take advantage of the potential that exists in the American generation by promising that America has unlimited ability to take risks and make new discoveries for the advancement of America. In addition, the American generation has proven their determination and perseverance. But, the realization can only be achieved if it is done together.
(19)"We do not believe that in this country freedom is reserved for the lucky, or happiness for the few. We recognize that no matter how responsibly we live our lives, any one of us at any time may face a job loss, or a sudden illness, or a home swept away in a terrible storm. The commitments we make to each other through Medicare and Medicaid and Social Security, these things do not sap our initiative, they strengthen us. They do not make us a nation of takers; they free us to take the risks that make this country great". (O2)

In this data (19), the speech act found is a commissive speech act. This commissive speech act has a function to give a promise that the American people will not be weak in their enthusiasm to take risks and advance the American state even though things may happen someday in the economic situation and their families. If these conditions occur, Obama promises to provide social security such as Medicare and Mediaid, so that citizens do not have to worry about it and keep the spirit to do better for the nation.

\section{Expressive Speech Act}

Expressive speech act is a speech act that expresses the psychological attitude of the speaker to the situation implicit in illocutionary. Expressive speech acts found in the data will be described as follows:

(20)"I stand here today humbled by the task before us, grateful for the trust you have bestowed, mindful of the sacrifices borne by our ancestors. I thank President Bush for his service to our nation, as well as"...(O1)

In this data (20), the speech acts found are expressive speech acts indicated by 
humbled, grateful and thankful performative verbs. Expressive speech acts in this context have a function to express Obama's feelings as a leader with good character. In this context, expressive speech acts with humbled performative verbs has a function to express Obama's humility with the task that will be carried out by him, namely to lead America in the future. Expressive speech acts with grateful performative verb have a function to express Obama's gratitude for the trust given by Americans by choosing him as the president of America for the present. Speech act with performative verb thankhas a function to express Obama's gratitude to the previous president, George W. Bush for leading America before Obama took over as a consequence of Obama's election in this presidential election.

(21)"As we consider the road that unfolds before us, we remember with humble gratitude those brave americans who, at this very hour, patrol far-off deserts and distant mountains"... (O1)

In this data (21), the speech acts found is expressive speech acts which are marked by the presence of humble performative verbs. Speech acts in this context has a function to express Obama's feelings that Obama highly appreciates Americans who are willing to work far to the desert and mountains just to serve the American people. Therefore, for Obama, they deserve to be considered like a hero. Thus, through this speech, Obama intends to reveal that he appreciates the services that have been done by these hard-working labours and hopes that this can be an example for the spirit of other Americans.

(22) "We honor them not only because they are guardians of our liberty, but because they embody the spirit of service; a willingness to find meaning in something greater than

themselves"... (O1)

In this data (22), the speech acts found are expressive speech acts, because they are characterized by the existence of performative verbs honorwhich means respect. This speech acts to express Obama's feelings that Obama appreciates his feelings for hard workers who are willing to go far to the desert and mountains to build America by assuming they are heroes. In addition, Obama and Americans in particular also respect them not because they are American guards, but for the spirit of their service to the country. Thus, the performatif verb honor has a function to express Obama's appreciation for these workers because of their strong enthusiasm and persistence in working for the United States itself.

(23)“Thank you. God bless you, and may He forever bless these United States of America". (O2)

In this data (23), the speech act found is expressive speech acts which are expressed explicitly through performative verb thankful. This expressive act has a function to express the feelings of the speaker to the opposite person. In this context, Obama wants to express his gratitude to all Americans who were present at the inauguration. In addition, Obama also expressed his feelings so that God would always bless all Americans, and also the United States.

\section{Declarative Speech Act}

In Declaration speech acts are speech acts in which if the implementation is successful will result in a match between the contents of the proposition and reality. As for the realization of this declarative speech act on the data can be described as follows: 
(24) “We, the people, declare today that the most evident of truths -- that all of us are created equal -- is the star that guides us still; just as it guided our forebears through Seneca Falls, and Selma, and Stonewall; just as it guided all those men and women, sung and unsung, who left footprints along this great Mall, to hear a preacher say that we cannot walk alone; to hear a King proclaim that our individual freedom is inextricably bound to the freedom of every soul on Earth".(O2)

In this data (24), the speech act found is declarative speech acts which are characterized by performative verb declare. This speech acts has a function to declare the real truth is that all Americans are born with the same rights and obligations, like stars who guide their ancestors and are also still guiding them today. The whole point is that Obama wants to emphasize that the freedom of each individual is strongly tied to the freedom of every soul in the world. This declarative speech actis to show the sacred equality of each American individual so that Obama expresses it through the declaration's speech act.

Based on the analysis, the types of speech acts found in each president's inauguration speech included five types of speech acts, namely assertive speech acts, directive speech acts, commissive speech acts, expressive speech acts, and declarative speech acts. In the first Obama inauguration speech, the types of speech acts found included four types of speech acts, namely assertive speech acts, commissive speech acts, directive speech acts, and expressive speech acts. Whereas in Obama's second inauguration speech, the speech acts found included all types of speech acts, namely directive, assertive, commissive, expressive, and declarative speech acts. From this explanation, it can be seen that there are differences in the types of speech acts encountered in Obama's first and second inauguration speeches. In Obama's first inaugural address, there were only four types of speech acts, while in the second inauguration speech there were all kinds of speech acts, which were not found in other inaugural speeches. This is because in his second administration, Obama wanted to give hope to Americans to build an American country to be better in the future, one of which is to erase the differences that exist in the United States. Therefore, Obama declared his plan through declarative speech acts. Directive speech act is the most frequent speech acts, while the least frequent speech acts is declarative speech act.

\section{Conclusion}

Based on data analysis that has been done, it can be concluded that the speech acts found in the American presidential inaugural address includes six types of speech acts, that is assertive, directive, commissive, expressive, declarative and phatic. However, declarative speech acts found in Obama's second inaugural address speech with one data only. The speech act used in the inauguration speech of the American president is inseparable from its various functions in speech, namely to express opinions, give information, give orders either directly or indirectly, give promises, express feelings, change propositions with truth and also to maintain relationship or friendship in society.

\section{References}

Austin, J. L. (1962). How to Do Things with Words. London: Oxford University Press.

Miller Center. (n.d.). Presidential Speeches. Retrieved October 22, 2018, from https://millercenter.org/the-presidency/ 
presidential-speeches

Mulyana. (2005). Kajian Wacana [Discourse Analysis]. Yogyakarta: Tiara Wacana.

Partai Politik di Amerika Serikat [Political Parties in the United States]. (2009). Retrieved May 17, 2018, from http:// yudisolo.blogspot.com/2009/04/partaipolitik-di-amerika-serikat.html

Rahardi, K. (2005). Pragmatik Kesantunan Imperatif Bahasa Indonesia [Pragmatics of Imperative Politeness in Bahasa Indonesia]. Jakarta, Indonesia: Erlangga.

Rohmadi, M. (2004). Pragmatik Teori dan Analisis [Theories and Analyses of Pragmatics]. Yogyakarta, Indonesia: Lingkar Media Jogja.

Sudaryanto. (1993). Metode dan Aneka Tehnik Analisis Bahasa (Pengantar Penelitian Wahana Kebudayaan secara Linguistik) [Methods and Techniques of Language Analyses: Introduction to Cultural Modes through Linguistics]. Yogyakarta, Indonesia: Duta Wacana University Press.

Wijana, I. D. P. (1996). Dasar-dasar Pragmatik [Fundamentals of Pragmatics]. Yogyakarta: Andi. 